\title{
Supplementation and monensin effects on digesta kinetics II. Cattle grazing winter range
}

\author{
MICHAEL G. WARD, DON C. ADAMS, JOE D. WALLACE, M.L. GALYEAN, AND JERRY D. VOLESKY
}

\section{Abstract}

Sixteen ruminally cannulated steers grazing Northern Great Plains native winter range were assigned to 4 treatments in $\approx 2 \times 2$ factorial arrangement. Main effects were protein and monensin. $A$ soybean meal-barley pellet (P; $26 \%$ crude protein) was fed at 0 and $.8 \mathrm{~kg} \bullet$ head $^{-1} \bullet \mathrm{d}^{-1}$. Steers either received no monensin (M) or M was released at $101 \mathrm{mg} / \mathrm{day}$ via a ruminal delivery device. Forage intake, ruminal fermentation, in vivo organic matter (OM) digestibility, and ruminal fuid passage and particulate digesta kinetics were measured during trials in November and January. Esophageally fistulated steers were used to collect diet samples during each trial. Dietary crude protein was greater $(P<0.01)$ in November $(8.3 \%)$ than January (4.9\%). Forage OM intake was not $(P>0.10)$ influenced by either $P$ or $M$. In vivo $O M$ digestibility was increased $(P<0.05)$ by $P(60.6$ vs $57.4 \%)$ and not afiected $(P>0.10)$ by $M$. Particulate passage rate increased $(P<0.05)$ when $P$ was combined with M. Ruminal fuid flow characteristics, fluid volume and pH were not affected $(P>0.10)$ by either $P$ or $M$. Ruminal ammonia-N was increased $(P<0.01)$ by $P(2.9$ vs $.6 \mathrm{mg} / 100 \mathrm{ml})$ and not affected $(P>0.10)$ by $M$. Total ruminal volatile fatty acid concentrations, along with molar proportions of ruminal propionate and butyrate, were not affected $(P>0.10)$ by $P$ or $M$. Ruminal acetate was decreased $(P<0.10)$ by $P$ and not influenced $(P>0.10)$ by $M$. We conclude that supplemental protein, through ruminal modifications, has beneficial effects on OM digestibility, and can thereby provide cattle grazing winter range with additional energy at a time when it is most crucial.

Key Words: particulate passage, fluid passage, digestibility, intake, rumen fermentation, forage, protein

Livestock grazing dormant winter range are often unable to consume sufficient quantities of forage to meet their energy and protein requirements. Supplemental protein and (or) monensin might enable cattle to meet their winter nutrient requirements. Supplemental protein has often increased forage and energy intake (Cook and Harris 1968, Kartchner 1980); however, data are inconclusive. Rittenhouse et al. (1970) and Judkins et al. (1987) reported no effect on forage intake as a result of protein supplementation. Monensin can increase nitrogen digestibility, decrease dietary protein requirements, and reduce degradation of dietary protein within the rumen, thereby eliciting a protein sparing effect (Schelling 1984, Bergen and Bates 1984). Clanton et al. (1981) reported that wintering range cows fed monensin had heavier weight calves than unsupplemented cows. The objective of this study was to quantify the effects of supplemental protein, monensin, and their interaction on intake, ruminal fermentation and ruminal fluid, and particulate digesta kinetics in beef steers grazing Northern Great Plains native winter range. Singularly and in combination, sup-

Authors are from Moorman Mfg. Co., 2314 Burlington Blvd., North Platte Nebraska 69101 ; University of Nebraska-Lincoln, West Central Research and Extension Center, Route 4, Box 46A, North Platte, Nebraska 69101 (formerly with USDA-ARS Miles City); and (3 and 4) Department of Animal and Range Science, Box 3-I, New Mexico State University, Ias Cruces 88003; and USDA-ARS at the Forage and Livestock Research Laboratory, P.O. Box 1199, El Reno, Okla. 73036.

This paper is a contribution from the U.S. Department of Agriculture, Agriculture Research Service, and Montana Agriculture Experiment Station, Miles City, and New Mexico State University, Las Cruces. Mention of a trade name or product does not constitute a recommendation or endorsement for use by the USDA.

Publication has been approved by the Director of the Montana Agr. Exp. Sta. Journal Ser. J-2321

Manuscript accepted 28 February 1990. plemental protein and monensin were hypothesized to beneficially alter ruminal fermentation, fluid flow, digesta kinetics, and intake.

\section{Materials and Methods}

Sixteen crossbred ruminally cannulated steers with an average initial weight of $390 \mathrm{~kg}$ grazed freely on a 48.6-ha, broken upland native range site from 29 October 1987 to 22 January 1988 . The stocking rate was considered to be light to moderate for this range (Holscher and Woolfolk 1953) and forage was readily available throughout the study. The range site was located on the Fort Keogh Livestock and Range Research Laboratory, Miles City, Montana. Major forage species were western wheatgrass ( Pascopyrum smithii [Rydb.] Löve); blue grama (Bouteloua gracilis [H.B.K.] Lag. ex. Griffiths); needle-and-thread grass (Stipa comata Trin. and Rupr.); buffalograss (Buchloe dactyloides [Nutt.] Engelm.); and threadleaf sedge (Carex filifolia Nutt.). Browse species available included greasewood (Sarcobatus vermiculatus [Hook.] Emory.); shadscale (Artiplex confertifolia [Torr. and Frem.] S. Wats.); Gardner's salt bush (Atriplex gardneri [Moa.] D. Dietr.); winterfat (Ceratoides lanata [Pursh] J.T. Howell); big sagebrush (Artemesia tridentata Nutt.); and silver sagebrush (Artemesia cana Pursh). Perennial forbs were rare.

Steers were assigned randomly to 4 supplementation treatments ( 4 steers/treatment) in a $2 \times 2$ factorial arrangement with main effects of protein (P) and monensin (M). A soybean meal-barley pellet ( $40 \%$ soybean meal, $55 \%$ rolled barley, and $5 \%$ molasses) containing $26.3 \%$ crude protein on dry matter (DM) basis was fed at either 0 or $.8 \mathrm{~kg} \bullet$ head $^{-1} \bullet \mathrm{d}^{-1}$. Monensin was either not dosed or was released at $101 \mathrm{mg} /$ day via a ruminal delivery devicel (MRDD) as described by Parrott et al. (1986). Protein was fed to individual steers, at approximately 0800 daily because this time was considered to be least disruptive to winter grazing behavior (Adams et al. 1986). Each MRDD was weighed at the beginning and end of the study and determined to have released an an average of $101 \mathrm{mg}$ of monensin/day. Ruminal fermentation variables, fluid passage rates, particulate digesta kinetics, organic matter (OM) intake, and in vivo OM digestibility were measured during 2 trials conducted from: (1) 15 to 20 November, and (2) 17 to 22 January.

Seven days before starting each trial, a mass esophageal extrusa sample was collected from the study pasture from 16 mature esophageally fistulated steers, composited across steers, and labeled with $\mathrm{Yb}$ for use as a particulate phase marker. To estimate particulate passage rate and gastrointestinal dry matter (DM) fill, each ruminally cannulated steer received an intraruminal pulse dose ( $180 \mathrm{~g} \mathrm{DM}$ in trial $1 ; 250 \mathrm{~g} \mathrm{DM}$ in trial 2) of Yb-labeled forage (3.39 $\mathrm{g} \mathrm{Yb}$ in trial $1 ; 4.44 \mathrm{~g} \mathrm{Yb}$ in trial 2) via the rumen cannula at 1800 on day 1 of each trial. To estimate ruminal fluid passage rate and volume, each steer received an intraruminal dose of $1,045 \mathrm{mg}$ of cobalt in a Co-ethylenediaminetetraacetate solution (EDTA; Uden et al. 1980) $12 \mathrm{~h}$ after (0600, day 2) Yb-labeled forage was dosed. Procedures for labeling esophageal extrusa with $\mathrm{Yb}$ and introduction of $\mathrm{Yb}$ labeled forage and Co-EDTA into the rumen were the same as those described by Ward et al. (1990).

Just before dosing with Co-EDTA, and again at 4, 8, 12, 16, 20,

${ }^{1}$ Monensin ruminal delivery devices were supplied by Lilly Research Laboratories, Greenfield, Indiana 46104 
24 , and $36 \mathrm{~h}$ after dosing, $100-\mathrm{ml}$ samples of ruminal fluid were withdrawn from the ventral sac of the rumen of each steer. The $\mathrm{pH}$ was determined immediately with a combination electrode, after which samples were strained through 4 layers of cheesecloth, acidified with $2 \mathrm{ml} .25 \mathrm{~N} \mathrm{H}_{2} \mathrm{SO}_{4}$, and frozen for later analysis. Fecal grab samples were taken from each steer at $0,12,16,20,24,28,32,36$, $42,48,54,60,72,84,96,108$, and $120 \mathrm{~h}$ after dosing with $\mathrm{Yb}$ labeled forage, dried at $45^{\circ} \mathrm{C}$, and ground to pass a $1-\mathrm{mm}$ screen. Adams et al. (1986) reported minimal grazing activity during nondaylight hours for cattle grazing winter native range. Hence, to facilitate ease of sample collection during trials, steers were gathered at dusk and penned in a large corral facility and released to graze at sunrise.

Laboratory procedures for determining ammonia-N, volatile fatty acid (VFA) and Co concentration of ruminal fluid samples and $\mathrm{Yb}$ concentration of fecal samples and mathematical procedures for determining particulate passage, fluid passage, forage intake, and digestibility have been described by Ward et al. (1990).

Five esophageally fistulated steers collected diet samples from the study pasture on the third day of each 6-d trial. They had grazed the study pasture 2-d before each sample collection. Esophageal collections began at about 0700 and lasted for 30 to $45 \mathrm{~min}$. Between trials, the steers grazed an adjacent pasture with similar plant composition. Esophageal steers were not supplemented during the study period. Esophageal samples were dried at $45^{\circ} \mathrm{C}$ and ground to pass a 1-mm screen. Esophageal samples were analyzed for crude protein, DM, and ash by standard methods (AOAC 1980). Neutral detergent fiber, acid detergent fiber, and acid detergent lignin of esophageal samples were determined by the nonsequential procedures of Goering and Van Soest (1970).

Ruminal fermentation measurements, ruminal fluid volume and fluid flow rates, along with intake, particulate passage, and in vivo digestibility, were analyzed by split-plot analysis of variance with the 4 treatments arranged in a $2 \times 2$ factorial as the main-plot and trial as the sub-plot (Gill and Hafs 1971) using the General Linear Models procedure of SAS (1985). Ruminal fermentation variables were averaged across samples taken at $0,4,8,12,16$, and $20 \mathrm{~h}$, and the mean was analyzed. Chemical composition of esophageal samples was analyzed as a split plot with no main plot and trial as the subplot (repeated measurements). Except where noted, significant differences are reported at the $P<0.10$ level.

\section{Results and Discussion}

The treatment by trial interaction was not significant for any of the variables tested in this study. Significant $(P<0.01)$ trial effects were noted only for intake and digestibility estimates.

\section{Nutrient Composition}

Chemical composition of fistula-collected forage samples during the 2 trial periods is presented in Table 1. Dietary crude protein was

Table 1. Chemical composition of diets of esophageal-fistulated steers.

\begin{tabular}{|c|c|c|c|}
\hline \multirow[b]{2}{*}{ Chemical component } & \multicolumn{2}{|c|}{ Trial } & \multirow[b]{2}{*}{ EMS } \\
\hline & 1 & 2 & \\
\hline Organic matter & \multicolumn{2}{|c|}{ - . \% of Dry Matter } & 3.57 \\
\hline $\begin{array}{l}\text { Crude protein } \\
\text { Neutral detergent fiber } \\
\text { Acid detergent fiber } \\
\text { Acid detergent lignin }\end{array}$ & $\begin{array}{r}--\% \text { of } \\
8.3 \mathrm{a} \\
84.8 \mathrm{a} \\
54.6 \mathrm{a} \\
5.9 \mathrm{a}\end{array}$ & $\begin{array}{r}\text { ic Matt } \\
4.9 \mathrm{~b} \\
84.8 \mathrm{a} \\
54.2 \mathrm{a} \\
5.3 \mathrm{a}\end{array}$ & $\begin{array}{l}.25 \\
2.94 \\
3.73 \\
.607\end{array}$ \\
\hline
\end{tabular}

IEMS = Error mean squares.

2Means in a row followed by different letters are significantly different at $\boldsymbol{P}<0.05$. greater $(P<0.01)$ and $O M$ was less $(P<0.05)$ in trial I than trial 2 , reflecting nutrient losses that occur from range forages with seasonal progression (Hogan 1984), and potential changes in diet selection. Neutral detergent fiber, acid detergent fiber, and acid detergent lignin did not vary by trial.

\section{Intake and Passage Rate}

Forage and total OM intake (Table 2) were not affected by $P$ or

Table 2. Intake, gastrointestinal tract, fill, particulate pasage and digestibility as infuenced by supplemental protein and monensin in steers graxing native range.

\begin{tabular}{|c|c|c|c|c|c|}
\hline \multirow[b]{2}{*}{ Item } & \multicolumn{4}{|c|}{ Treatment" } & \multirow[b]{2}{*}{ EMS $^{\mathbf{b}}$} \\
\hline & NR & $\mathrm{NR}+\mathrm{M}$ & $\mathrm{NR}+\mathrm{P}$ & $\mathrm{NR}+\mathrm{P}+\mathrm{M}$ & \\
\hline $\begin{array}{l}\text { Forage organic matter } \\
\text { intake, } \\
\mathrm{kg} \cdot \mathrm{d}^{-1} \cdot 100 \mathrm{~kg}^{-10 d y} \mathrm{wt}^{-1}\end{array}$ & 1.6 & 1.5 & 1.5 & 1.4 & .032 \\
\hline $\begin{array}{l}\text { Total organic matter intake, } \\
\mathrm{kg} \cdot \mathrm{d}^{-1} \cdot 100 \mathrm{~kg}^{-1} \text { body wt }\end{array}$ & 1.6 & 1.5 & 1.7 & 1.6 & .032 \\
\hline $\begin{array}{l}\text { Gastrointestinal tract fill, } \\
\text { kg dry matter }\end{array}$ & $5.1^{\mathrm{c}}$ & 5.7 & 4.4 & 4.2 & .440 \\
\hline $\begin{array}{l}\text { Particulate passage } \\
\text { rate, } \% \bullet \mathrm{h}^{-1}\end{array}$ & $2.6^{d}$ & 2.4 & 2.8 & 3.1 & .050 \\
\hline Total mean retention time, $h$ & $66.5^{\mathrm{c}}$ & 67.0 & 59.4 & 53.6 & 83.3 \\
\hline $\begin{array}{l}\text { Forage Organic matter } \\
\text { digestibility, } \%\end{array}$ & $57.3^{c}$ & 57.5 & 60.7 & 60.6 & 6.88 \\
\hline
\end{tabular}

NR=native range, $P=$ protein pellet, $M=$ monensin.

'EMS=Error mean squares.

Protein effect significant $(P<0.05)$.

${ }^{d}$ Protein $\times$ Monensin interaction $(P<0.05)$.

M. Forage and total intake (forage plus supplement) estimates were greater than those reported by Judkins et al. (1987) for steers grazing blue grama winter range in New Mexico. Protein supplementation effects on forage intake have been variable, and explanations regarding variability are not defined clearly in the literature (Cook and Harris 1968, Rittenhouse et al. 1970, Kartchner 1980). Lack of an intake response to protein supplementation in the present study may have resulted from relatively mild weather conditions. The mean minimum daily temperature was $-4.8^{\circ} \mathrm{C}$ in trial 1 and $-13.0^{\circ} \mathrm{C}$ in trial 2 . As temperatures decline, grazing time and forage intake decrease (Adams 1987). Consequently, a greater effect of supplemental protein may be elicited during colder winter conditions when intake is expected to be lower. This concept concurs with Kartchner (1980), where supplemental protein had no effect on forage intake during mild winters and a substantial effect during harsh winters. A suppression in intake because of monensin as reported by Lemenager et al. (1978a) for cows grazing winter range contrasts results from the present study. Variation between studies may be the result of nonuniformity in range forage species (i.e., cool vs warm-season), environmental conditions, method of $M$ delivery, and differences in animal type.

Forage OM digestibility was increased $(P<0.05)$ by $P$, but not affected by $M$. Protein supplementation would be expected to positively influence $\mathrm{OM}$ digestibility because ruminal ammonia- $N$ concentrations (Table 3) of nonsupplemented steers were well below levels suggested (Slyter et al. 1979) as optimal for microbial growth. Improved forage digestibility increases total energy available to the animal and can lead to improved performance of cattle consuming mature winter forage (Kartchner 1980, Ward and Ward 1987). Other researchers (Dinius et al. 1976, Lemenager et al. 1978b) also reported no effects of $M$ on digestibility of winter range grass.

Gastrointestinal tract dry matter fill and mean retention time were decreased $(P<0.05)$ by $P$ while a $P \times M$ interaction $(P<0.05)$ occurred for particulate passage rate. Protein combined with $M$ produced an additional increase in particulate passage rate above 
Table 3. Ruminal fluid flow and volume, rumen pH and rumen ammonin$\mathbf{N}$ concentration as influenced by supplemental protein and monensin in steers graxing native range.

\begin{tabular}{lccccc}
\hline \hline & \multicolumn{5}{c}{ Treatment $^{\mathrm{a}}$} \\
\cline { 2 - 5 } Item & $\mathrm{NR}$ & $\mathrm{NR+M}$ & $\mathrm{NR+P}$ & $\mathrm{NR}+\mathrm{P}+\mathrm{M}$ & EMS $^{\mathrm{b}}$ \\
\hline Fluid passage rate, \%/h & 10.0 & 9.8 & 11.7 & 10.6 & 3.14 \\
Tumover time, h & 10.2 & 10.7 & 8.8 & 9.9 & 3.10 \\
Flow rate, liters/h & 3.7 & 5.9 & 4.1 & 5.9 & 14.2 \\
Volume, liters & 37.4 & 56.6 & 35.0 & 51.1 & 887.5 \\
pH & 6.54 & 6.56 & 6.40 & 6.41 & .080 \\
Ammonia-N, mg/100 ml & $.62^{\mathrm{c}}$ & .58 & 2.62 & 3.25 & 2.70 \\
\hline
\end{tabular}

NR=native range, $P=$ protein pellet, $M=$ monensin

bMS=Error mean squares.

'Protein effect significant $(P<0.01)$

that of $\mathbf{P}$ alone. Cattle consuming mature winter forage have particulate digesta kinetics regulated by complex intra-ruminal relationships among intake, digestion, and rate of passage (Ward and Ward 1987). For animals consuming mature forage, feed intake is limited by ruminal distension (Montgomery and Baumgardt 1965), which is partially alleviated by rumination and microbial digestion of ingested feedstuffs, allowing passage through the gastrointestinal tract (Waldo et al. 1972). Increased digestion of mature forages can facilitate faster rates of passage, which could eventually lead to increased feed intake (Faulkner et al. 1985). Gastrointestinal tract fill and gastrointestinal mean retention time were not affected by $M$, which contrasts reported decreases in particulate turnover rate when feeding monensin (Lemenager et al. 1978b).

Ruminal fluid flow characteristics and volume (Table 3) were not affected by $P$ or M. Judkins et al. (1987) also found no changes in fluid flow characteristics or fluid volume when steers grazing winter native range were supplemented with protein. Lemenager et al. (1978b) reported decreased ruminal fluid passage rate and volume when monensin was fed to steers consuming winter range grass, contradicting results in the present study. However, amounts of monensin given and experimental conditions differed between studies. Total $\mathbf{O M}$ intake did not increase as a result of $\mathbf{P}$ or $\mathbf{M}$ supplementation; therefore, corresponding increases in ruminal fluid passage rate and volume would not be expected (Grovum and Hecker 1973).

\section{Ruminal Fermentation}

Ruminal $\mathrm{pH}$ was not influenced by $\mathrm{P}$ or $\mathrm{M}$ (Table 3), which is consistent with other data regarding $P$ and $M$ (Dinius et al. 1976, McCollum and Galyean 1985, Judkins et al. 1987). Ruminal ammonia- $\mathrm{N}$ was increased $(P<0.01)$ by $P$, but not influenced by $M$ (Table 3). McCollum and Galyean (1985) reported increased ruminal ammonia- $\mathrm{N}$ concentrations when steers receiving low-quality prairie hay were fed supplemental protein. Dinius et al. (1976) and Lemenager et al. (1978b) also reported no difference in ruminal ammonia- $\mathrm{N}$ concentrations resulting from monensin supplementation. Supplemental $\mathbf{P}$ increased ammonia- $\mathbf{N}$ to concentrations generally considered optimal for microbial growth. Controversy surrounds ruminal ammonia- $\mathrm{N}$ levels regarding actual requirements of ruminal microbes. Slyter et al. (1979) recommend $2.2 \mathrm{mg}$ ammonia-N/100 $\mathrm{ml}$ of ruminal fluid. Qrskov (1982) suggested that ruminal levels of $2 \mathrm{mg}$ ammonia- $\mathrm{N} / 100 \mathrm{ml}$ is sufficient for maximum microbial growth, while Stanton et al. (1983) indicated a range of 2.7 to $4.5 \mathrm{mg}$ rumen ammonia- $\mathrm{N} / 100 \mathrm{ml}$ is sufficient for maintaining beef cows grazing winter range. Hespell and Bryant (1979) proposed rumen ammonia-N levels of .1 to $.2 \mathrm{mg} / 100 \mathrm{ml}$ as the concentration at which microbial growth becomes limited and that ruminal ammonia- $\mathrm{N}$ concentration does not necessarily relate to ruminal bacteria intracellular concentrations, which is most important for growth. Furthermore, ruminal bacterial growth is also influenced by amino acids and peptides (Argyle and Baldwin 1989).

Total concentration of ruminal VFA (Table 4) was not affected by $P$ or $M$, which concurs with findings of McCollum and Galyean (1985). The effects of protein supplementation on molar proportions of VFA are conflicting and inconclusive. Results from the

Table 4. Ruminal concentrations of total volatile fatty acids (VFA) and molar proportions of acetate, propionate, butyrate, valerate, isovalerate and isobutyrate as infuenced by supplemental protein and monensin in steers grazing native range.

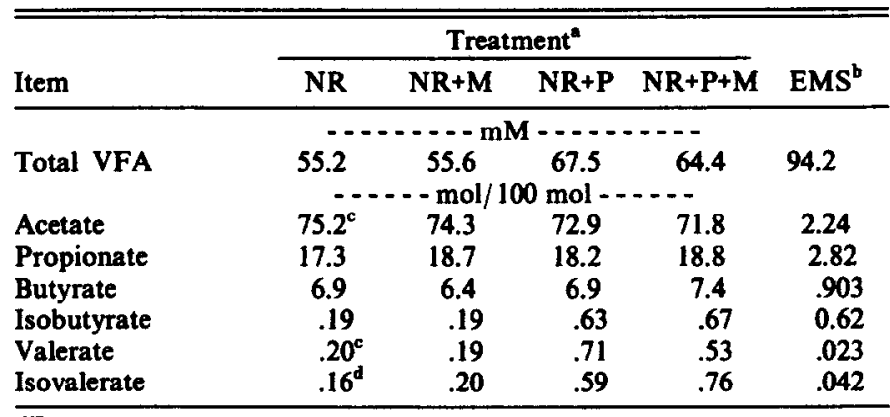

NNR =native range, $P=$ protein pellet, $M=$ monensin.

${ }^{b}$ EMS=Error mean squares.

'Protein effect significant $(P<0.10)$

${ }^{d}$ Protein effect significant $(P<0.05)$.

present study showed that molar proportions of ruminal acetate were decreased by $\mathbf{P}$ and not affected by $\mathbf{M}$. Moreoever, molar concentrations of propionate and butyrate were not affected by either P or M. McCollum and Galyean (1985) also reported decreases in molar proportions of ruminal acetate resulting from protein supplementation, while Wagner et al. (1983) found no differences in molar proportions of VFA in protein-supplemented cattle grazing rangelands. Results from the present experiment concerning monensin contrast those of Lemenager et al. (1978b), in which monensin decreased molar proportions of ruminal acetate and increased molar proportions of ruminal propionate in steers fed harvested winter range grass. Monensin levels fed by Lemenager et al. (1978b) were twice those of the present study and steers were fed in drylot, which may explain why results varied between studies. In addition, Lemenager et al. (1978b) fed monensin as a pulse dose, as opposed to a continuous release as in the present study. Valerate and isovalerate were increased by $P(P<0.10$ and $P<0.05$, respectively) and not affected by $M$. Isobutyrate was not affected by either $P$ or $M$. On protein deficient diets, minor acids would be expected to increase as a result of protein supplementation because branched-chain acids are primarily derived from degradation of dietary protein (Qrskov 1982).

\section{Conclusions}

Ruminal ammonia- $N$ concentrations were increased by supplemental protein, which led to a concomitant increase in organic matter digestibility. While forage intake was not increased by protein supplementation, gastrointestinal tract dry matter fill and particulate mean retention time were reduced. When supplemental protein was combined with monensin, an additional increase in particulate passage rate occurred. Increased forage digestibility and particulate passage rate, along with reduced gastrointestinal mean retention time, could combine to provide cattle grazing winter range additional energy at a time when it is most critical to meet nutrient requirements. 


\section{Literature Cited}

Adams, D.C. 1987. Influence of winter weather on range livestock. Proc. Graz. Livestock Nutr. Conf. Univ. of Wyoming, Jackson, Wyoming. pp. 115-121.

Adams, D.C., T.C. Nelson, W.L. Reynolds, and B.W. Knapp. 1986. Winter grazing activity and forage intake of range cows in the northern great plains. J. Anim. Sci. 62:1240-1246.

AOAC. 1980. Official methods of analysis (13th Ed.) Assoc. Offic. Analyt. Chem. Washington, D.C.

Artyle, J.L., and R.L. Baldwin. 1989. Effects of amino acids and peptides on rumen microbial yields. J. Dairy Sci. 72:2017-2027.

Bergen, W.C., and D.B. Bates. 1984. Ionophores: their effect on production efficiency and mode of action. J. Anim. Sci. 58:1465-1483.

Clanton, D.C., M.E. England, and J.C. Parrott III. 1981. Effect of monensin on efficiency of production in beef cows. J. Anim. Sci. 53:873-880.

Cook, C.W., and L.E. Harris. 1968. Effect of supplementation on intake and digestibility of range forage. Utah Agr. Exp. Sta. Bull. 475.

Dinius, D.A., M.S. Simpson, and P.B. Marsh. 1976. Effect of monensin fed with forage on digestion and the ruminal ecosystem of steers. J. Anim. Sci. 42:229-234.

Faulkner, D.B., G.L. Llames, J.K. Ward, and T.J. Klopienstein. 1985. Improving the intake and nutritive value of wheat straw for beef cows. Anim. Feed Sci. Tech. 12:125-132.

Gill, J.L., and H.D. Hafs. 1971. Analysis of repeated measurements of animals. J. Anim. Sci. 33:331-336.

Goering, H.K., and P.J. Van Soest. 1970. Forage fiber analyses. USDAARS Agr. Handbk. 379.

Grovum, W.L., and J.F. Hecker. 1973. Rate of passage of digesta in sheep. 2. The effect of level of food intake on digesta retention times and on water and electrolyte absorption in the large intestine. Brit. J. Nutr. 30:221-230.

Hespell, R.B., and M.D. Bryant. 1979. Efficiency of rumen microbial growth: influence of some theoretical and experimental factors on $Y_{\text {ATP. }}$ J. Anim. Sci. 49:1640-1659.

Hogan, J.P. 1984. Digestion and utilization of proteins. In: J.B. Hacker (ed.), Nutritional limits to animal production from pastures, Proc. Int. Symp., St. Lucia, Queensland, Australia. Commonwealth Agr. Bureaux, Farnham Royal.

Holscher, C.E., and E.J. Woolfolk. 1953. Forage utilization by cattle on Northern Great Plains Ranges. USDA Circular 918.

Judkins, M.L., J.D. Wallace, M.L. Galyean, L.J. Krysl, and E.E. Parker. 1987. Passages rates, rumen fermentation and weight change in protein supplemental grazing cattle. J. Range Manage. 40:100-104.

Kartchner, R.J. 1980. Effects of protein and energy supplementation of cows grazing native winter range forage on intake and digestibility. $J$. Anim. Sci. 51:432-438.
Lemenager, R.P., F.N. Owens, K.S. Lusby, and R. Totusek. 1978 . Monensin, forage intake and lactation of range beef cows. J. Anim. Sci. 47:247-254.

Lemenazer, R.P., F.N. Owens, B.J. Shockey, K.S. Lusby, and R. Totusek. 1978b. Monensin effects on rumen turnover rate, twenty-four hour VFA pattern, nitrogen components and cellulose disappearance. J. Anim. Sci. 47:255-261.

MeCollum, F.T., and M.L. Galyean. 1985. Influence of cottonseed meal supplementation on voluntary intake, rumen fermentation and rate of passage of prairie hay in beef steers. J. Anim. Sci. 60:570-577.

Montgomery, M.S., and B.R. Baumgardt. 1965. Regulation of food intake in ruminants. 2. Pelleted rations varying in energy concentrations. J. Dairy Sci. 48:569-574.

Grkov, E.R. 1982. Protein nutrition in ruminants. Academic Press, New York.

Parrott, J.C., R.P. Basson, J.M. Conrad, N.G. Elliston, H.P. Grueter, F.E. Livesay, J.W. McAskill, R.M. Meyer, R.D. Olson, and L.C. Pendlum. 1986. Effect on monensin ruminal delivery devices on rate of weight gain of pasture cattle. J. Anim. Sci. 63(Suppl. 1):304 (Abstr.).

Rittenhouse, L.R., D.C. Clanton, and C.L. Streeter. 1970. Intake and digestibility of winter-range forage by cattle with and without supplements. J. Anim. Sci. 31:1215-1221.

SAS. 1985. SAS/STAT user's guide for personal computers, Version 6 Ed., SAS Institute, Inc., Cary, N.C.

Schelling, G.T. 1984. Monensin mode of action in the rumen. J. Anim. Sci. 58:1518-1527.

Slyter, L.L., L.D. Satter, and D.A. Dinius. 1979. Effect of ruminal ammonia concentration on nitrogen utilization by steers. J. Anim. Sci. 48:906-912.

Stanton, T.L., F.N. Owens, and K.S. Lusby. 1983. Formaldehyde-treated soybean meal for ruminants grazing winter range grass. J. Anim. Sci. 56:6-14.

Uden, P., D.E. Colucel, and P.J. Van Soest. 1980. Investigation of chromium, cerium and cobalt as markers in digesta rate of passage studies. J. Sci. Food Agr. 31:625-632.

Wagner, J.J., K.S. Lusby, and G.W. Horn. 1983. Condensed molasses solubles, corn steep liquor and fermented ammoniated condensed whey as protein sources for beef cattle grazing dormant native range. J. Anim. Sci. 57:542-552.

Waldo, D.R., L.W. Smith, and E.L. Cox. 1972. Model of cellulose disappearance from the rumen. J. Dairy Sci. 55:125-129.

Ward, M.G., and J.K. Ward. 1987. Ammoniation of warm-season grass hay for gestating beef cows. J. Anim. Sci. 65:359-365.

Ward, M.G., D.C. Adams, J.D. Wallace, M.L. Galyean, and B.W. Knapp. 1990. Supplementation and monensin effects on digestive kinetics I. Cattle grazing summer range. J. Range Manage. (43:378-382).

\section{Moving?}

If you are changing your address, notifying the post office is not sufficient to keep your journal coming on time. Please send your new address and the label with your old address to the Society for Range Management, 1839 York Street, Denver, Colorado 80206, USA. 